\title{
Lymphocyte populations in liver biopsy specimens from patients with chronic liver disease
}

\author{
J. SANCHEZ-TAPIAS, H. C. THOMAS, AND S. SHERLOCK \\ From The Medical Unit, The Royal Free Hospital, Hampstead, London
}

SUMMARY The characterisation of lymphocytes from liver biopsies indicates that 'activated' $\mathrm{T}$ lymphocytes are present in the liver in alcohol induced hepatitis, chronic active hepatitis $\left(\mathrm{HB}_{\mathrm{s}}+\mathrm{ve}\right.$ and -ve), and in primary biliary cirrhosis but not in inactive cirrhosis, chronic persistent hepatitis, extrahepatic and drug induced cholestasis. A greater percentage of lymphocytes bear Fc-receptors in chronic active hepatitis than in alcohol induced hepatitis or cholestatic liver disease. The concentration of 'activated' $\mathrm{T}$ cells in the peripheral blood in all groups studied was within the normal range, suggesting that the 'activated' $T$ cells found in the liver were reacting to either native or foreign antigens within the liver. The data on Fc-receptor bearing cells are consistent with the involvement of antibody assisted $\mathrm{K}$ cell mediated cytotoxicity in chronic active hepatitis.

Several lines of evidence suggest that immunological mechanisms may contribute to the pathogenesis of some types of chronic liver disease. In vitro studies have demonstrated that the peripheral blood lymphocytes of patients with lupoid or type B chronic active hepatitis are cytotoxic for heterologous (Thomson et al., 1974), homologous (Wands and Isselbacher 1975; Jacques et al., 1976), and autologous (Paronetto and Vernace, 1975) liver cells, and that the cell responsible for this hepatocytotoxicity is the $\mathrm{K}$ lymphocyte, an Fc-receptor bearing lymphocyte with the capacity to destroy antibody coated target cells (Jacques et al., 1976). In alcohol induced liver disease, sensitisation of peripheral blood lymphocytes to a liver cell component (Mihas et al., 1975), and, in primary biliary cirrhosis, the association with autoantibody formation and abnormalities of immunoglobulin production (Thomas et al., 1976 b) suggest that immunological factors also contribute to these diseases.

Studies of peripheral blood lymphocyte populations have demonstrated decreased T-lymphocyte concentrations in lupoid and hepatitis B virus induced chronic liver disease (De Horatius et al., 1974), in primary biliary cirrhosis (Thomas et al., 1976 a) and in alcohol related liver disease (Bernstein et al., 1974). Many of these changes relate to the presence of serum inhibitors which influence rosette formation (Chisari and Edgington, 1975),

Received for publication 20 December 1976 and do not necessarily indicate direct involvement of $T$ cells in the pathogenesis of the disease.

We have used rosetting techniques to identify lymphocytes obtained from liver biopsies as $T$, 'activated' T, or Fc-receptor bearing cells to provide further evidence on the possible involvement of these cells in autoimmune, viral, and alcohol related liver disease.

\section{Methods}

Fifteen patients with alcohol related liver disease (ALD), 11 with $\mathrm{HB}_{\mathrm{s}} \mathrm{Ag}$ positive chronic active hepatitis, seven with $\mathrm{HB}_{\mathrm{s}} \mathrm{Ag}$ negative chronic active hepatitis, and 12 with cholestasis were studied. Five patients with $\mathrm{HB}_{\mathrm{s}} \mathrm{Ag}$ negative $\mathrm{CAH}$ were receiving immunosuppressive drugs. Peripheral blood specimens from these patients and from 15 normal subjects were also studied.

ISOLATION OF CELLS FROM LIVER TISSUE Liver specimens obtained by aspiration needle biopsy were used for routine histology and for preparation of a single cell suspension. Twenty milligrams of liver were washed in cold Eagle's medium supplemented with $10 \%$ fetal calf serum (FCS), and teased into small pieces which were then suspended with $1 \mathrm{ml}$ of medium in a plastic tube and shaken for five minutes at room temperature. Isolated cells were separated from tissue debris by allowing the debris to sediment 
through fetal serum over a 10 minute period. The supernatant containing the cells was centrifuged, the pellet washed, and resuspended in $0.4 \mathrm{ml}$ of medium. The final suspension contained variable numbers of liver cells, lymphocytes, monocytes, granulocytes, and a few erythrocytes. Bile ductular and plasma cells were rarely identified. The debris contained strands of fibrous material with only small numbers of cells.

The efficiency of retrieval of cells from the biopsy could not be calculated because the total number of cells in the starting material could not be determined. The retrieval is likely to be high because examination of the debris failed to reveal significant numbers of cells. However, in the absence of this exact data absolute concentrations of lymphocytes per unit weight of liver could not be estimated. We have therefore looked at the composition of the cellular infiltrate, expressing the data as percentages. It is unlikely that the efficiency of retrieval of the different lymphocyte populations varies between the different disease groups and therefore, although the population obtained is only a sample of the total infiltrate, it is nevertheless representative and gives an indication of the proportions of different cell types in the original population.

\section{IMMUNOCYTOCHEMICAL TECHNIQUES}

$\mathrm{T}$ lymphocytes and Fc-receptor bearing cells (monocytes, granulocytes, $\mathrm{B}$ and $\mathrm{K}$ lymphocytes) were identified by $\mathrm{E}$ (Jondal et al., 1972) and EA rosetting techniques (Jondal and Klein, 1973). Monocytes and granulocytes were differentiated from $\mathrm{B}$ and $\mathrm{K}$ lymphocytes by the myeloperoxidase staining technique (Preud'Homme and Flandrin, 1974). In brief, $0 \cdot 1 \mathrm{ml}$ of the suspension of cells obtained from the liver biopsy was mixed with $0.1 \mathrm{ml}$ of the appropriate sheep red blood cell suspension, left for five minutes at room temperature and then centrifuged for five minutes at $200 \mathrm{~g}$. The tubes containing EA cells were incubated at $37^{\circ} \mathrm{C}$ for 30 minutes and those with $\mathrm{E}$ cells $12-18$ hours at $4^{\circ} \mathrm{C}$. 'Activated' $\mathrm{T}$ cells were identified by their ability to form rosettes with fresh group $O$ rhesus negative human erythrocytes (Sheldon and Holbrow,
1975). These erythrocytes (H cells) were washed three times with phosphate buffered saline and resuspended in Eagle's medium supplemented with $20 \%$ FCS to give a $0 \cdot 1 \%$ suspension; $0.1 \mathrm{ml}$ of this suspension was added to $0.1 \mathrm{ml}$ of the liver cell suspension and the mixture was processed as for E-rosette formation.

After incubation, the cells were carefully resuspended in $0.05 \mathrm{ml}$ of medium and fixed for 20 minutes with $1.5 \%$ gluteraldehyde at $4^{\circ} \mathrm{C}$. The cells were smeared on glass slides, air dried, and treated with Graham-Karnovsky mixture (5 mg 3.3 diaminobenzidine per $10 \mathrm{ml}$ of Tris- $\mathrm{HCl}$ buffer $\mathrm{pH} 7.6$ in the presence of added $\mathrm{H}_{2} \mathrm{O}_{2}$ ). After washing with distilled water, the preparations were conterstained with $0.01 \%$ methyl green for 10 minutes, washed, air dried, and mounted. The slides were coded and examined by ordinary light microscopy. Two hundred lymphocytes were counted and those fixing three or more erythrocytes were scored as rosetting cells. The criteria for identification of cells are given in Table 1.

\section{PERIPHERAL BLOOD}

Lymphocytes were obtained by sedimentation on a Ficoll-Triosyl density gradient, washed, and resuspended in medium at a final concentration of $4 \times 10^{6}$ lymphocytes per $\mathrm{ml} ; 0.1 \mathrm{ml}$ of this suspension was added to $0.1 \mathrm{ml}$ of the appropriate red blood cell suspension and the mixtures were processed as previously described. The percentage of rosette forming cells was calculated after counting 200 cells.

\section{Results}

The yield of cells obtained by mechanical disruption of liver tissue varied considerably from patient to patient. The concentration of cells in the final suspension ranged from 37 to $86 \times 10^{3}$ cells per $\mathrm{ml}$ for hepatocytes and from 13 to $22 \times 10^{3}$ cells per ml for leucocytes. Variations in the ratio of hepatocytes to leucocytes did not appear to have any effect on the efficiency of the rosetting process. Contamination of the specimens with blood was negligible, as the ratio of erythrocytes:leucocytes found in the

Table 1 Method of identification of cells isolated from liver tissue

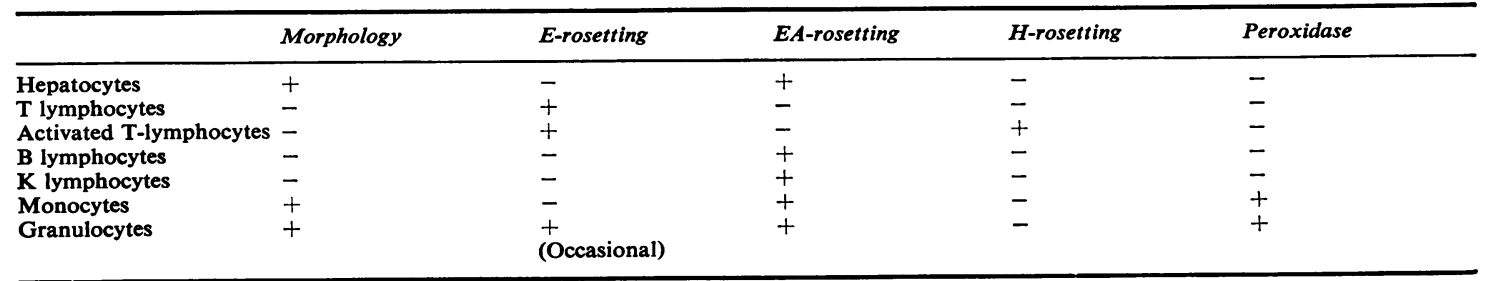


suspensions of isolated cells was very low (less than 1:4).

Identification of the different cells according to the criteria given in Table 1 was easily achieved.

The percentage of lymphocytes identified as $\mathrm{T}$ cells in the liver biopsy population was significantly higher than in peripheral blood $(P<0.001)$ in patients with alcoholic hepatitis and $\mathrm{HB}_{\mathrm{s}} \mathrm{Ag}$ positive and negative chronic active hepatitis. There was no significant difference between liver and peripheral blood in fatty liver, inactive cirrhosis, chronic persistent hepatitis, and primary biliary cirrhosis.

The percentage of cells which were 'activated' $\mathrm{T}$ cells (H-rosette forming cells) was significantly higher in the liver than in blood in patients with alcoholic hepatitis $(\mathrm{P}<0.001), \mathrm{HB}_{\mathrm{s}} \mathrm{Ag}$ positive chronic active hepatitis $(\mathrm{P}<0.001), \mathrm{HB}_{\mathrm{s}} \mathrm{Ag}$ negative chronic active hepatitis $(P<0.05)$, and primary biliary cirrhosis $(\mathrm{P}<0.001)$. No significant differences between blood and liver were found in patients with fatty liver, inactive alcoholic cirrhosis, and chronic persistent hepatitis. Furthermore, the percentage of activated $T$ cells in the liver was significantly higher in patients with alcoholic hepatitis than in the other alcoholic patients $(P<0.005)$, in patients with chronic active hepatitis than in those with chronic persistent hepatitis $(P<0.005)$, and in patients with primary biliary cirrhosis than in other forms of cholestasis ( $P<0.02)$.

The percentage of cells forming rosettes with EA cells (B and $K$ lymphocytes) (monocytes were identified by peroxidase staining) in the liver was significantly higher than in peripheral blood in patients with $\mathrm{HB}_{\mathrm{S}} \mathrm{Ag}$ positive and negative chronic active hepatitis $(P<0.05)$, but was the same in the other groups studied (Table 2).

\section{Discussion}

The most significant finding in this study is the presence of significant numbers of $\mathbf{H}$-rosette forming cells in the lymphocyte population obtained from liver specimens from patients with alcohol induced hepatitis, chronic active hepatitis, and primary biliary cirrhosis. In contrast, these cells represented a much smaller proportion of the cells derived from patients with steatosis, inactive cirrhosis, chronic persistent hepatitis, extrahepatic, and drug induced cholestasis. Although the exact nature of these cells is not fully established, existing studies suggest that they represent a subpopulation of $T$ lymphocytes which have undergone activation either by an antigen or mitogen (Sheldon and Holborow, 1975). Their presence in liver biopsy specimens from patients with active hepatocellular liver disease and primary biliary cirrhosis, but not in inactive disease or other forms of cholestasis, raises the possibility that a $\mathrm{T}$ cell mediated immune reaction is occurring in the liver of patients with active liver disease. The presence of normal percentages of these cells in the peripheral blood implies that the process of 'activation' occurs in the liver rather than in the peripheral blood and presumably is a response to exposure to either a mitogen or a native or denatured antigenic component of the liver, or in the case of hepatitis B virus induced disease, to a viral antigen. Whether this T-cell mediated reaction is of primary or secondary importance in the pathogenesis of these diseases remains uncertain.

In general, the lymphocyte population derived from the liver did not reflect the diminished $T$ cell percentages found in the peripheral blood of subjects with either cirrhosis or active hepatitis. It seems likely that the diminished peripheral blood con-

Table 2 Comparison of lymphocyte populations in liver and peripheral blood $(M \pm S E M)$

\begin{tabular}{|c|c|c|c|c|c|c|c|c|c|c|}
\hline \multirow[t]{2}{*}{ Disease group } & \multirow[t]{2}{*}{ No. } & \multicolumn{3}{|c|}{$\% E-R G C$} & \multicolumn{3}{|c|}{$\% E A-R F C$} & \multicolumn{3}{|c|}{$\% H-R F C$} \\
\hline & & Liver & Blood & $P$ value & Liver & Blood & $P$ value & Liver & Blood & $P$ value \\
\hline $\begin{array}{l}\text { Alcohol induced } \\
\text { Fatty liver } \\
\text { Inactive cirrhosis } \\
\text { Hepatitis } \pm \text { cirrhosis }\end{array}$ & $\begin{array}{l}4 \\
4 \\
7\end{array}$ & $\begin{array}{l}69 \pm 4 \\
65 \pm 12 \\
62 \pm 1\end{array}$ & $\begin{array}{l}63 \pm 1 \\
40 \pm 2 \\
42 \pm 1\end{array}$ & $\begin{array}{l}\text { NS } \\
\text { NS } \\
<0.001\end{array}$ & $\begin{array}{l}30 \pm 2 \\
28 \pm 8 \\
32 \pm 4\end{array}$ & $\begin{array}{l}33 \pm 1 \\
24 \pm 1 \\
28 \pm 4\end{array}$ & $\begin{array}{l}\text { NS } \\
\text { NS } \\
\text { NS }\end{array}$ & $\begin{array}{r}8 \pm 2 \\
7 \pm 1 \\
20 \pm 2\end{array}$ & $\begin{array}{l}3 \pm 1 \\
3 \pm 1 \\
2 \pm 2\end{array}$ & $\begin{array}{l}\text { NS } \\
\text { NS } \\
<0.001\end{array}$ \\
\hline $\begin{array}{l}\mathrm{HB}_{\mathbf{s}}+\text { ve hepatitis } \\
\text { Chronic persistent } \\
\text { Chronic active }\end{array}$ & $\begin{array}{l}6 \\
5\end{array}$ & $\begin{array}{l}59 \pm 3 \\
72 \pm 4\end{array}$ & $\begin{array}{l}70 \pm 6 \\
44 \pm 4\end{array}$ & $\begin{array}{l}\text { NS } \\
<0.001\end{array}$ & $\begin{array}{l}36 \pm 6 \\
43 \pm 3\end{array}$ & $\begin{array}{l}25 \pm 6 \\
30 \pm 4\end{array}$ & $\begin{array}{l}\text { NS } \\
<0.05\end{array}$ & $\begin{array}{r}5 \pm 2 \\
26 \pm 5\end{array}$ & $\begin{array}{l}2 \pm 1 \\
2 \pm 1\end{array}$ & $\begin{array}{l}\text { NS } \\
<0.001\end{array}$ \\
\hline $\begin{array}{c}\mathrm{HB}_{\mathbf{s}} \text { - ve hepatitis } \\
\text { Chronic active }\end{array}$ & 7 & $67 \pm 5$ & $48 \pm 3$ & $<0.01$ & $40 \pm 5$ & $26 \pm 2$ & $<0.02$ & $13 \pm 5$ & $2 \pm 1$ & $<0.05$ \\
\hline $\begin{array}{l}\text { Cholestasis } \\
\text { Extrahepatic } \\
\text { Drug induced } \\
\text { Primary biliary cirrhosis }\end{array}$ & $\begin{array}{l}5 \\
3 \\
4\end{array}$ & $\begin{array}{l}72 \pm 3 \\
63 \pm 3 \\
62 \pm 8\end{array}$ & $\overline{56} \pm 2$ & - & $\begin{array}{l}37 \pm 8 \\
28 \pm 1 \\
38 \pm 10\end{array}$ & $\overline{30} \pm 3$ & $\overline{\mathbf{N S}}$ & $\begin{array}{r}11 \pm 2 \\
6 \pm 3 \\
29 \pm 7\end{array}$ & $\overline{-}$ & $\frac{-}{<0.001}$ \\
\hline Controls & 15 & - & $65 \pm 2$ & - & - & $31 \pm 2$ & - & - & $2 \pm 1$ & - \\
\hline
\end{tabular}


centrations of these cells (Bernstein et al., 1974; Thomas et al., 1976 a) is dependent on the presence of serum inhibitors which prevent rosette formation (Chisari and Edgington, 1975) and result in increased concentrations of null cells (Thomas et al., 1976 a). These null cells are not found in the population of cells derived from the liver, possibly because the serum inhibitor prevents not only rosette formation but also the functional activity of this subpopulation of $\mathrm{T}$ lymphocytes.

The possibility of antibody assisted K-lymphocyte mediated cytotoxicity being involved in the pathogenesis of both $\mathrm{HB}_{\mathbf{s}}$ antigen positive and negative chronic active hepatitis has arisen from in vitro experiments (Cochrane et al., 1976; Jacques et al., 1976). Our finding of an increased percentage of Fc-receptor bearing cells in the liver of these patients compared with the peripheral blood, and also significantly higher percentages than in liver specimens from patients with alcohol induced disease, lends further support for the involvement of these cells in chronic active hepatitis. This population of cells includes $\mathrm{B}$ and $\mathrm{K}$ lymphocytes but not monocytes which have been excluded after myeloperoxidase staining. Since both $\mathbf{B}$ and $\mathrm{K}$ lymphocytes are involved in antibody assisted cellular cytotoxicity, there presence in increased concentrations in chronic active hepatitis is at least compatible with the involvement of this mechanism in this disease process. In this respect, our data are similar to those of Husby et al. (1975).

These data add further support for the involvement of $T$ lymphocytes in chronic hepatocellular liver disease whether alcohol or virus induced or autoimmune, and also in primary biliary cirrhosis. The antigens to which these cells are sensitised remains unknown and may well be different in each disease. Our data suggesting the accumulation of Fc-receptor bearing cells in the liver of patients with chronic active hepatitis is compatible with the involvement of antibody assisted $\mathrm{K}$-cell mediated cytotoxicity in chronic active hepatitis but not in alcohol related liver disease.

\section{References}

Bernstein, I. M., Webster, K. H., Williams, R. C., and
Strickland, R. G. (1974). Reduction in circulating T lymphocytes in alcoholic liver disease. Lancet, 2, 488-490.

Chisari, F. V., and Edgington, T. S. (1975). Lymphocyte E rosette inhibitory factor: a regulatory serum lipoprotein. Journal of Experimental Medicine, 142, 1092-1107.

Cochrane, A. M. G., Moussouros, A., Thomson A. D., Eddleston, A. L. W. F., and Williams, R. (1976). Antibodydependent cell-mediated (K-cell) cytotoxicity against isolated hepatocytes in chronic active hepatitis. Lancet, 1 , 441-444.

De Horatius, R. J., Strickland, R. G., and Williams, R. C. (1974). $T$ and $B$ lymphocytes in acute and chronic hepatitis. Clinical Immunology and Immunopathology, 2, 353-360.

Husby, G., Strickland, R. G., Caldwell, J. L., and Williams, R. C. (1975). Localization of T and B cells and alphafetoprotein in hepatic biopsies from patients with liver disease. Journal of Clinical Investigation, 56, 1198-1209.

Jacques, E., De Villiers, D., Thomas, H. C., and Sherlock, S. (1976). Lymphocyte mediated cytotoxicity for Chang liver disease. Abstract. Gut, 17, 389.

Jondal, M., and Klein, G. (1973). Surface markers on human $B$ and T lymphocytes II. Presence of Ebstein-Barr virus receptors on B lymphocytes. Journal of Experimental Medicine, 138, 1365-1378.

Jondal, M., Holm, G., and Wigzell, H. (1972). Surface markers on human $T$ and $B$ lymphocytes. I. A large population of lymphocytes forming non-immune rosettes with sheep red blood cells. Journal of Experimental Medicine, 136, 207-215.

Mihas, A. A., Bull, D. M., and Davidson, C. S. (1975). Cell-mediated immunity to liver in patients with alcoholic hepatitis. Lancet, 1, 951-953.

Paronetto, F., and Vernace, S. (1975). Immunological studies in patients with chronic active hepatitis: cytotoxic activity of lymphocytes to autochthonous liver cells grown in tissue culture. Clinical and Experimental Immunology, 19, 99-104.

Preud'Homme, J-L., and Flandrin, G. (1974). Identification by peroxidase staining of monocytes in surface immunofluorescence tests. Journal of Immunology, 113, 1650-1653.

Sheldon, P. J., and Holborow, E. J. (1975). H-rosette formation in T-cell-proliferative diseases. British Medical Journal, 4, 381-383.

Thomas, H. C., Freni, M., Sanchez-Tapias, J., De Villiers, D., Jain, S., and Sherlock, S. (1976a). Peripheral blood lymphocyte populations in chronic liver disease. Clinical and Experimental Immunology, 26, 222-227.

Thomas, H. C., Holden, R., Verrier Jones, J., and Peacock, D., (1976b). The immune response to $\phi X 174$ in man. 5 . Primary and secondary antibody production in primary biliary cirrhosis. Gut, 17, 844-848.

Thomson, A. D., Cochrane, M. A. G., MacFarlane, I. G., Eddleston, A. L. W. F., and Williams, R. (1974). Lymphocyte cytotoxicity to isolated hepatocytes in chronic active hepatitis. Nature, 252, 721-722.

Wands, J. R., and Isselbacher, K. J. (1975). Lymphocyte cytotoxicity to autologous liver cells in chronic active hepatitis. Proceedings of the National Academy of Sciences, 72, 1301-1303. 